\title{
SIMULTANEOUS ENZYMATIC HYDROLYSIS AND LACTIC FERMENTATION TO OBTAIN A YOGURT WITH LOW LACTOSE CONTENT
}

\author{
Hidrólise enzimática e fermentação lática simultâneas na obtenção \\ de um iogurte com baixo teor de lactose \\ André Rosa Martins', Ricardo Lemos Monteiro², \\ Janaína Fernandes de Medeiros Burkert ${ }^{3}$, Carlos André Veiga Burkert ${ }^{3}$
}

\begin{abstract}
In a single-stage process with the simultaneous addition of $\beta$-galactosidase and lactic culture, the lactose conversion, the processing time, viscosity and syneresis were evaluated. Fermentation was promoted by lactic culture containing two probiotic microorganisms, Bifidobacterium animalis and Lactobacillus acidophilus, associated with the typical microorganisms of yogurt. An enzymatic preparation containing $\beta$-galactosidases from Kluyveromyces lactis and Aspergillus niger was used. A central composite design ( $2^{3}$ trials plus three central points) was proposed in order to evaluate the effects of initial lactose concentration, enzyme concentration and the time of addition of the enzyme. The following conditions were established: initial lactose concentration of $91 \mathrm{~g} \mathrm{~L}^{-1}$, enzyme concentration of $0.5 \mathrm{~g} \mathrm{~L}^{-1}$ and enzyme addition at the beginning of fermentation. In these conditions, a decrease in processing time (from 4.55 to $3.68 \mathrm{~h}$ ) and an increase in lactose conversion (from 15.2 to $97.9 \%$ ) were observed in relation to the fermentation without enzyme addition, and no detrimental changes in some physical properties of yogurt (viscosity, and syneresis).
\end{abstract}

Index terms: Enzymatic catalysis, lactose hydrolysis, yogurt physical properties, $\beta$-galactosidase.

\section{RESUMO}

No processo em um único estágio com a adição simultânea de $\beta$-galactosidase e de cultura lática, foram avaliadas a conversão da lactose, o tempo de processamento, a viscosidade e a sinérese. A fermentação foi promovida por cultura láctica, contendo dois micro-organismos probióticos, Bifidobacterium animalis e Lactobacillus acidophilus, associados aos micro-organismos característicos do iogurte. Foi utilizado um preparado enzimático contendo $\beta$-galactosidases obtidas de Kluyveromyces lactis e de Aspergillus niger. Os efeitos da concentração inicial de lactose, concentração de enzima e tempo de adição da enzima foram avaliados por meio de um planejamento experimental ( $2^{3}$ ensaios mais três pontos centrais). As seguintes condições foram estabelecidas: concentração inicial de lactose de $91 \mathrm{~g} \mathrm{~L}^{-1}$, concentração de enzima de $0.5 \mathrm{~g} \mathrm{~L}^{-1}$ e adição da enzima no início da fermentação. Nessas condições, um decréscimo no tempo de processamento (de 4,55 h para 3,68 h) e um incremento na conversão de lactose (de 15,2\% para 97,9\%) foram observados em relação à fermentação sem a adição da enzima, sem alterações prejudiciais em algumas propriedades físicas do iogurte (viscosidade, e sinérese).

Termos para indexação: Catálise enzimática, hidrólise da lactose, propriedades físicas do iogurte, $\beta$-galactosidase.

(Received in may 20, 2012 and approved in july 17, 2012)

\section{INTRODUCTION}

Lactose intolerance affects a significant proportion of the worldwide adult population, with a major impact on the Asian, African, Amerindian and Aboriginal communities, with levels that may exceed 90\% (SCHAAFSMA, 2008; SWALLOW, 2003).

Lactose intolerance can be due to genetic factors. In individuals with lactase-nonpersistence, dietary lactose is not or is incompletely split by intestinal lactase, and residual lactose is fermented by the colonic microbiota, resulting in abdominal symptoms such as diarrhea, abdominal distress and flatulence. A single threshold of lactose for all lactose intolerant subjects cannot be determined owing to the great variation in individual tolerances. Symptons of lactose intolerance have been described after intake of less than $6 \mathrm{~g}$ of lactose in some subjects, and the only satisfactory treatment of lactose intolerance is a diet with reduced lactose content (EUROPEAN FOOD SAFETYAUTHORITY-EFSA, 2010).

$\beta$-galactosidase (EC 3.2.1.23) is an enzyme that catalyses the hydrolysis of lactose to glucose and galactose. It is potentially important in the production of lactose-reduced products in the food and dairy industry

${ }^{1}$ Instituto Federal de Educação, Ciência e Tecnologia do Rio Grande do Sul/IFRS - Rua Ramiro Barcelos - 2.777 - Bairro Santana - $90035-007$ - Porto Alegre - RS - Brasil - andre.martins@poa.ifrs.edu.br

2Universidade Federal do Rio Grande/FURG - Rio Grande - RS - Brasil

${ }^{3}$ Universidade Federal do Rio Grande/FURG - Escola de Química e Alimentos - Rio Grande - RS - Brasil 
for lactose intolerant populations. Moreover, $\beta$ galactosidase can be used in milk products such as icecream, frozen milk, whey spreads and condensed milk in order to avoid lactose crystallization, resulting in products with a mealy, sandy or gritty texture, and also to improve some technological properties, such as increasing digestibility, softness and creaminess (GROSOVÁ; ROSENBERG; REBROS, 2008). Additionally, considerable amounts of oligosaccharides are also formed during the reaction, and are considered bifidogenic factors (FANARO et al., 2009).

Since the 1970s, some studies have suggested that yogurt consumption might help to improve lactose intolerance. The presence of $\beta$-galactosidase activity in the cells of the lactic bacteria would be responsible for better lactose digestion. However, the persistence of gastrointestinal malaise from the consumption of yogurt shows the activity of $\beta$-galactosidase in the culture would not be sufficient to relieve the symptoms of indigestion. This led to the introduction of improvements to the product, such as reduced lactose content through exogenous lactases (RODRIGUEZ; CRAVERO; ALONSO, 2008).

The addition of $\beta$-galactosidase in the manufacturing of low-lactose fermented milks usually occurs at different stages. In the conventional process, enzymatic catalysis first occurs in a substrate at $\mathrm{pH}$ between 6.5 and 6.8 and temperatures between 4 and $6^{\circ} \mathrm{C}$, for the purpose of minimizing microbiological contamination. This temperature takes the contact time to at least $30 \mathrm{~h}$. In this conventional process, the substrate with low lactose content passes to the second stage of processing when the industrial application of lactic culture and early fermentation take place (MARTINS et al., 2011).

On the order hand, commercial enzymes available on the market have, in general, a range of action close to neutral pH (7.0 - 6.5) and are obtained from Kluyveromyces yeasts, or act at an acidic $\mathrm{pH}(5.5$ to 4.5$)$ and are obtained from Aspergillus molds. Their application to reduce the lactose content in milk products is widely known (JURADO et al., 2004). More recently, commercial preparations capable of acting on a wide range of $\mathrm{pH}$ have been available and hold great potential for use in lactic fermentation because hydrolytic activity remains throughout acidification process.

In this study, a single-stage process to obtain a yogurt with low lactose content was proposed, involving simultaneous enzymatic catalysis promoted by the commercial $\beta$-galactosidase preparation Lactomax Flex, a mixture of Kluyveromyces lactis and Aspergillus niger $\beta$ galactosidases, and lactic fermentation promoted by the commercial lactic culture ABY-3, in order to overcome the drawbacks of the two-stage process. A $2^{3}$ Central Composite Design (CCD) was proposed in order to verify the impact of process variables on parameters such as lactose conversion, processing time, viscosity and syneresis.

\section{Substrate \\ MATERIAL AND METHODS}

The substrate was obtained from whole milk powder and whey powder, both from Elegê (BR Foods, Brazil). The milk powder was used in all experiments in a single reconstitution at a proportion of $9 \% \mathrm{w} / \mathrm{v}$. Whey powder was added in different proportions $(1.5,3.5$ and $5.5 \% \mathrm{w} / \mathrm{v})$ to achieve the initial lactose values expressed in the experimental design and control fermentations.

\section{Enzyme preparation}

The commercial enzyme Lactomax Flex (Prozyn, Brazil) was used, a liquid formulation composed of $\beta$ galactosidases produced from Kluyveromyces lactis and Aspergillus niger.

\section{Lactic culture}

The commercial freeze-dried ABY-3 lactic culture was used (Chr Hansen, Brazil), containing Lactobacillus delbruekii subs. bulgaricus, Streptococcus salivarius subs. thermophilus, Bifidobacterium animalis and Lactobacillus acidophilus.

\section{Lactic fermentation}

As recommended by the manufacturer, the content of the lactic culture package was added to $500 \mathrm{~mL}$ of UHT milk and packaged in previously sterilized bottles. The inoculum $\left(10^{11} \mathrm{CFU} \mathrm{mL} \mathrm{mL}^{-1}\right)$ was stored under refrigeration and $4 \mathrm{~mL}$ dosed in each batch of $2 \mathrm{~L}$ of substrate. The substrate underwent heat treatment at $90 \pm 1^{\circ} \mathrm{C}$ for $5 \pm 1 \mathrm{~min}$ to denature the protein and minimize contamination risks. The fermentation processes were carried out in a Biostat B fermentor (B. Braun Biotech International, Germany), with 2 $\mathrm{L}$ capacity. The temperature was kept at $43^{\circ} \mathrm{C}$. The fermentation process was interrupted by cooling when $\mathrm{pH}$ reached 4.70 .

\section{Experimental design}

First, control fermentations (CO1 to $\mathrm{CO} 3$ ), without enzyme addition, were prepared using different initial lactose concentrations (Table 1) in order to obtain reference values for processing time $\left(\mathrm{t}_{\mathrm{p}}\right)$, viscosity $(\mathrm{V})$, syneresis $(\mathrm{S})$ and lactose conversion $\left(\mathrm{L}_{\mathrm{c}}\right)$. 
Table 1 - Control fermentations (without enzyme addition).

\begin{tabular}{cccccc}
\hline Run & $\mathrm{L}_{0}\left(\mathrm{~g} \mathrm{~L}^{-1}\right)$ & $\mathrm{t}_{\mathrm{P}}(\mathrm{h})$ & $\mathrm{V}(\mathrm{cP})$ & $\mathrm{S}(\% \mathrm{w} / \mathrm{w})$ & $\mathrm{L}_{\mathrm{C}}(\%)$ \\
\hline $\mathrm{C} 01$ & 59 & 4.45 & 2013 & 80.49 & 19.8 \\
$\mathrm{C} 02$ & 75 & 4.38 & 2104 & 78.41 & 15.2 \\
$\mathrm{C} 03$ & 91 & 4.55 & 2451 & 76.30 & 13.8 \\
\hline
\end{tabular}

$\mathrm{L}_{0}$ : initial lactose concentration; $\mathrm{t}_{\mathrm{p}}$ : processing time; $\mathrm{V}$ : viscosity; $\mathrm{S}$ : syneresis; $\mathrm{L}_{\mathrm{C}}$ : lactose conversion.

Following this, in a single-stage process with simultaneous exogenous b-galactosidase action and lactic fermentation, a $2^{3}$ Central Composite Design (CCD) with three central points was proposed, resulting in a total of 11 trials (Table 2) in order to evaluate the effects of initial lactose concentration $\left(\mathrm{L}_{0}\right)$, enzyme concentration $(\mathrm{E})$ and the time of addition of the enzyme $(\mathrm{t})$ on the parameters of processing time, viscosity, syneresis and lactose conversion. Data were treated using Statistica 5.0 software (Statsoft Inc., United States).

\section{Analytical determinations}

\section{Syneresis}

The syneresis (S) was evaluated by centrifugation, in accordance with Amatayakul, Sherkat and Shan (2006). A sample of $10 \mathrm{~g}$ of fermented product was weighed in a centrifuge tube and stored at $4^{\circ} \mathrm{C}$ for $2 \mathrm{~h}$ to achieve stabilization. The sample was centrifuged at $4000 * \mathrm{~g}$ for 10 min and the whey obtained was separated and weighed. The syneresis was expressed as whey mass percentage in relation to the total mass weight of the gel sample.

\section{Viscosity}

The viscosity (V) was analyzed by a DV-E digital viscometer (Brookfield, United States) using spindle 62. The samples were analyzed at $10^{\circ} \mathrm{C}$ and $10 \mathrm{rpm}$. The equipment presents a viscosity reading in centipoise (cP) and this occurs after $20 \mathrm{~s}$ of measurement have elapsed.

\section{Lactose concentration}

The lactose conversion $\left(\mathrm{L}_{\mathrm{C}}\right)$ was obtained by the ratio of the initial and final lactose concentrations, both of which were analyzed using the K-Lacgar enzymatic kit (Megazyme, Ireland), with absorbance reading at $340 \mathrm{~nm}$ (Cary 100 Conc UV-Visible spectrophotometer, Varian, United States), according to the instructions of the manufacturer. The samples were first clarified using Carrez I solution (3.60 $\mathrm{g}$ of $\mathrm{K}_{4}[\mathrm{Fe}(\mathrm{CN}) 6] .3 \mathrm{H}_{2} \mathrm{O}$ in $100 \mathrm{~mL}$ of distilled water), Carrez II solution $\left(7.20 \mathrm{~g} \mathrm{ZnSO}_{4} .7 \mathrm{H}_{2} \mathrm{O}\right.$ in $100 \mathrm{~mL}$ of distilled water) and $100 \mathrm{mM} \mathrm{NaOH}$ solution.

\section{RESULTSAND DISCUSSION}

\section{Control fermentations}

Table 1 presents the results of processing time, viscosity, syneresis and lactose conversion for control fermentations ( $\mathrm{C} 01$ to $\mathrm{C} 03$ ). The results indicate a low lactose conversion (from 13.8 to $19.8 \%$ ) for the fermentation without enzyme, similar to that observed by Lamoureux, Roy and Gauthier (2002) (about 20\%). Furthermore, lactose conversion decreased with the increase in initial lactose concentration.

Table 2 - Coded levels and real values (in the parenthesis) for the experimental design.

\begin{tabular}{cccccccc}
\hline Run & $\mathrm{L}_{0}\left(\mathrm{~g} \mathrm{~L}^{-1}\right)$ & $\mathrm{E}\left(\mathrm{g} \mathrm{L}^{-1}\right)$ & $\mathrm{t}(\mathrm{h})$ & $\mathrm{t}_{\mathrm{P}}(\mathrm{h})$ & $\mathrm{V}(\mathrm{cP})$ & $\mathrm{S}(\% \mathrm{w} / \mathrm{w})$ & $\mathrm{L}_{\mathrm{C}}(\%)$ \\
\hline 1 & $-1(59)$ & $-1(0.5)$ & $-1(0)$ & 3.55 & 1701 & 77.24 & 98.8 \\
2 & $+1(91)$ & $-1(0.5)$ & $-1(0)$ & 3.68 & 2343 & 74.79 & 97.9 \\
3 & $-1(59)$ & $+1(1.0)$ & $-1(0)$ & 3.67 & 1962 & 75.89 & 99.7 \\
4 & $+1(91)$ & $+1(1.0)$ & $-1(0)$ & 3.85 & 2193 & 73.94 & 99.2 \\
5 & $-1(59)$ & $-1(0.5)$ & $+1(1)$ & 3.90 & 2001 & 76.56 & 98.5 \\
6 & $+1(91)$ & $-1(0.5)$ & $+1(1)$ & 3.98 & 1797 & 77.13 & 97.7 \\
7 & $-1(59)$ & $+1(1.0)$ & $+1(1)$ & 3.97 & 1450 & 79.17 & 99.5 \\
8 & $+1(91)$ & $+1(1.0)$ & $+1(1)$ & 4.05 & 1539 & 77.35 & 98.7 \\
9 & $0(75)$ & $0(0.75)$ & $0(0.5)$ & 3.97 & 1636 & 77.85 & 99.3 \\
10 & $0(75)$ & $0(0.75)$ & $0(0.5)$ & 3.95 & 1696 & 77.84 & 99.2 \\
11 & $0(75)$ & $0(0.75)$ & $0(0.5)$ & 3.99 & 1687 & 77.90 & 99.2 \\
\hline
\end{tabular}

$\mathrm{L}_{0}$ : initial lactose concentration; $\mathrm{E}$ : enzyme concentration; $\mathrm{t}$ : time of addition of the enzyme; $\mathrm{t}_{\mathrm{p}}$ : processing time; V: viscosity; $\mathrm{S}$ : syneresis; $\mathrm{L}_{\mathrm{C}}$ : lactose conversion. 
The processing time ranged from 4.38 to $4.55 \mathrm{~h}$. The viscosity in fermentation ranged from 2013 to $2451 \mathrm{cP}$, while the interval of the syneresis ranged from 76.30 to $80.49 \% \mathrm{w} / \mathrm{w}$. The syneresis values lie within the range reported by Amatayakul et al. (2006) for yogurts with 9\% solids $(70-80 \% \mathrm{w} / \mathrm{w})$. According to the authors, the increased concentration of solids prevents (reduces) syneresis. As for the viscosity, Marafon et al. (2011), claim that the increased viscosity may be linked to the increased level of solids of the milk base. Therefore, whereas in the control fermentations the solids content corresponded to $9.8,11.7$ and $13.5 \% \mathrm{w} / \mathrm{w}$ for $\mathrm{CO} 1$, $\mathrm{CO} 2$ and $\mathrm{CO} 3$, respectively, it can be said that the decrease in syneresis and the increase in viscosity shown in table 1 are associated with this increment in the solids content.

\section{Maximization of lactose conversion}

In order to obtain a yogurt with low lactose content, without significant changes in viscosity and syneresis in relation to the fermentation without enzyme addition, a $2^{3}$ CCD was proposed and the results are presented in table 2 . It can be seen that the lactose conversion ranged from 97.7 to $99.7 \%$, processing time ranged from 3.55 to $4.05 \mathrm{~h}$, viscosity ranged from 1450 to $2343 \mathrm{cP}$ and syneresis ranged from 73.94 to $79.17 \% \mathrm{w} / \mathrm{w}$.

An important increase in lactose conversion can be observed in all the experiments when compared with fermentation without enzyme. An empirical coded model (Equação 1) was proposed to describe lactose conversion as a function of initial lactose concentration, enzyme concentration and the time of addition of the enzyme. Table 3 shows the analysis of variance (ANOVA) used to evaluate the adequacy of the fitted model $(\mathrm{p}<0.05)$. The correlation coefficient (0.93) and $\mathrm{F}$ test (3.3 times higher than the listed value) were very good. Consequently, the coded model was considered predictive and can be used to generate the response surfaces for lactose conversion (Figure 1).

$$
L_{C}=-0.375 * L_{0}+0.525 * E-0.15 * t
$$

Regarding lactose conversion, the best result was obtained when there was a higher enzyme concentration (1.0 $\left.\mathrm{g} \mathrm{L}^{-1}\right)$ and a lower initial lactose concentration $\left(59 \mathrm{~g} \mathrm{~L}^{-1}\right)$, as shown in figure 1-A. According to figure 1-B the ideal for obtaining a yogurt with the highest possible lactose conversion is the addition of the enzyme in the early stages of fermentation together with the lactic culture $(0 \mathrm{~h})$ using substrate with a lower initial lactose concentration $\left(59 \mathrm{~g} \mathrm{~L}^{-1}\right)$. The variation of lactose conversion in relation to the enzyme concentration and the time of addition of the enzyme (Figure 1-C) indicated that the best condition is the highest enzyme concentration $\left(1.0 \mathrm{~g} \mathrm{~L}^{-1}\right)$ when this is added at the beginning of the process $(0 \mathrm{~h})$. Under these conditions, a lactose conversion of $99.4 \%$ was achieved.

Therefore, the processing conditions for maximizing lactose conversion to obtain yogurt with a low lactose level are an initial lactose concentration of $59 \mathrm{~g} \mathrm{~L}^{-1}$, enzyme concentration at $1.0 \mathrm{~g} \mathrm{~L}^{-1}$ and the addition of the enzyme at the beginning of the fermentation process, together with the lactic culture $(0 \mathrm{~h})$. These conditions correspond to Run 3 (Table 2).

These results were significant when compared to those cited in the literature. In the work of Toba, Arihara and Adachi (1986), which produced yogurt through the simultaneous addition of b-galactosidase from Aspergillus oryzae, the authors achieved a lactose conversion of $64 \%$ in $8 \mathrm{~h}$ of processing. According to Longo and Waszsczynskyj (2006), lactose reduction was $88 \%$ in a $4 \mathrm{~h}$ treatment of pasteurized milk with commercial enzyme obtained from Kluyveromyces lactis applied prior to fermentation. Rodriguez, Cravero and Alonso (2008) conducted simultaneous fermentation and catalysis using goat milk as a substrate and an enzyme from Aspergillus oryzae, applied together with the lactic culture. They obtained a conversion of up to $82.6 \%$ based on a substrate with initial lactose concentration of $44.2 \mathrm{~g} \mathrm{~L}^{-1}$. In the present study, it was possible to obtain values between 97.7 and $99.7 \%$ of lactose conversion, compared with the conversion between 13.8 and $19.8 \%$ for the fermentation without enzyme addition.

\section{Effects on the physical properties of yogurt}

Figure 2 shows the effects of the initial lactose concentration, the enzyme concentration and the time of addition of the enzyme on processing time, viscosity and syneresis.

Table 3 - ANOVA for lactose conversion.

\begin{tabular}{ccccc}
\hline Source of Variation & Sum of squares & Degrees of freedom & Mean squares & $\mathrm{F}_{\text {(calculated) }}$ \\
\hline Regression & 3.51 & 3 & 1.17 & 14.44 \\
Residual & 0.57 & 7 & 0.08 & \\
Total corrected & 4.08 & 10 & & \\
\hline $\mathrm{F}_{\text {(tabulated) } 3,7,0.05}=4.35 ; \mathrm{R}=0.93$. & & &
\end{tabular}

Ciênc. agrotec., Lavras, v. 36, n. 5, p. 551-559, set./out., 2012 


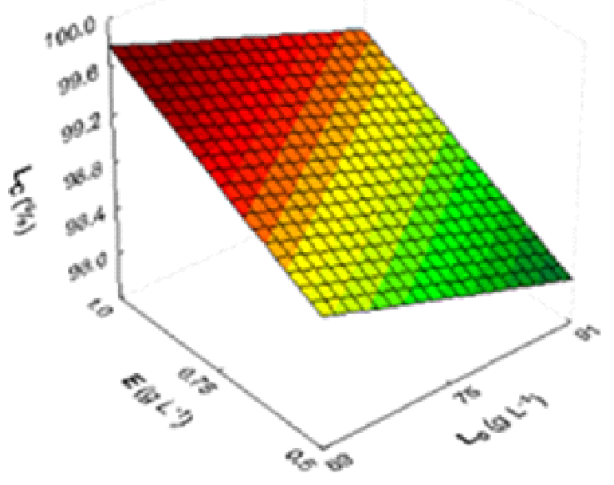

A
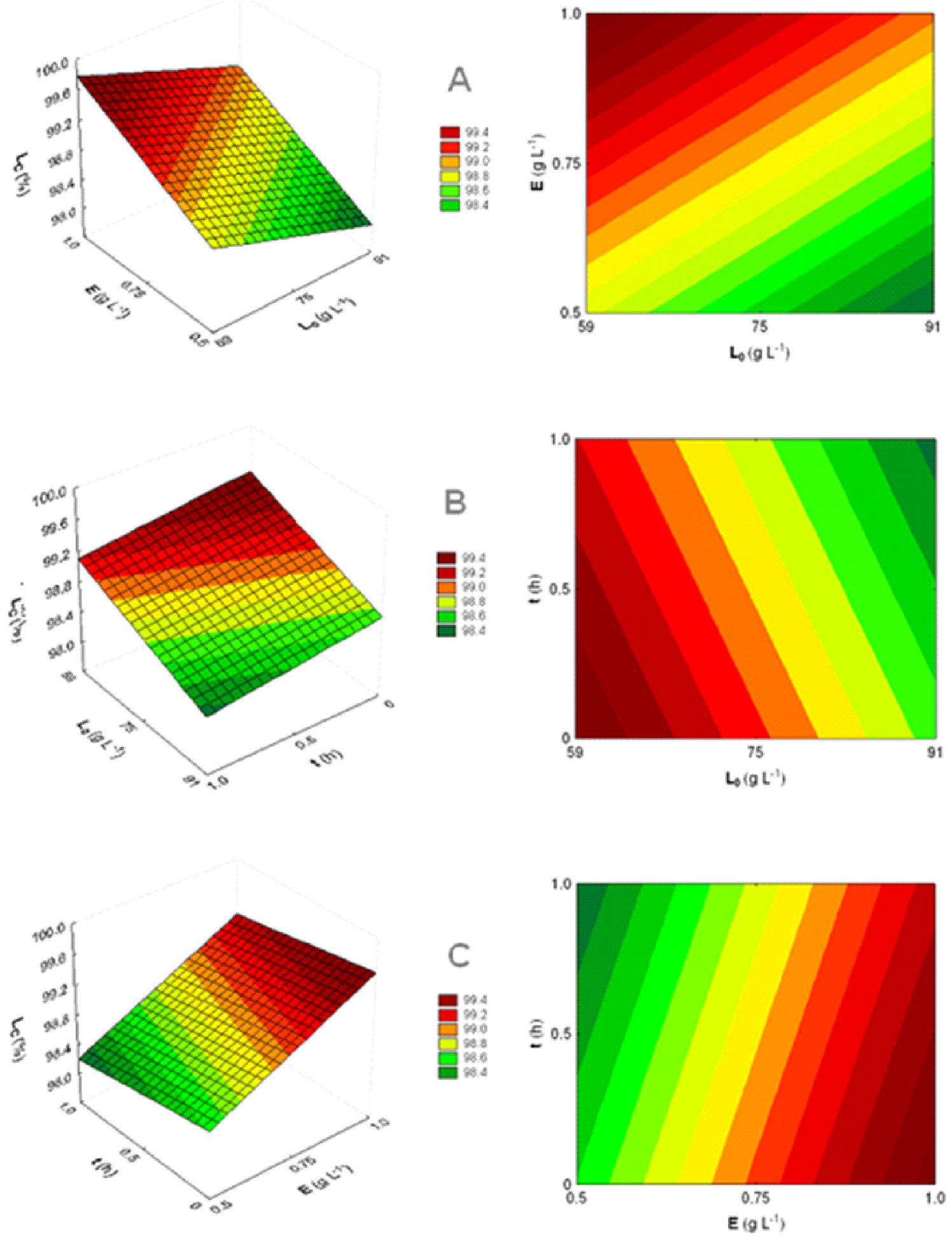

Figure 1 - Response surfaces and contour diagrams for lactose conversion $\left(\mathrm{L}_{\mathrm{c}}\right)$ as a function of enzyme concentration (E) and initial lactose concentration $\left(\mathrm{L}_{0}\right)(\mathrm{A})$, time of addition of the enzyme $(\mathrm{t})$ and initial lactose concentration $\left(\mathrm{L}_{0}\right)(\mathrm{B})$ and enzyme concentration $(\mathrm{E})$ and time of addition of the enzyme $(\mathrm{t})(\mathrm{C})$. 
A

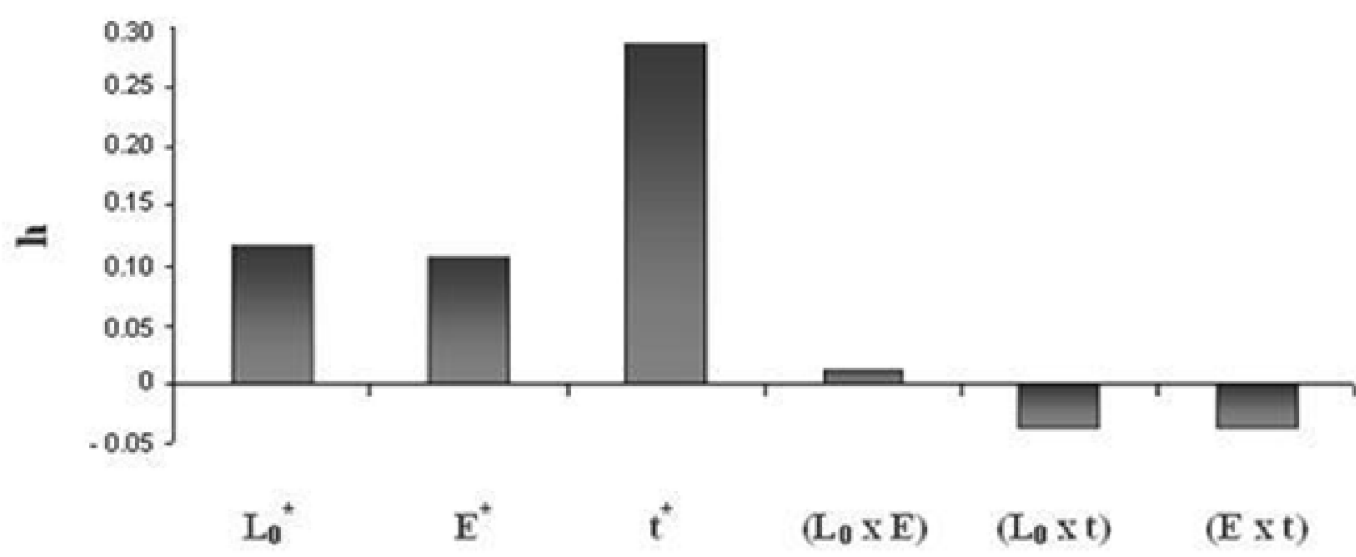

B
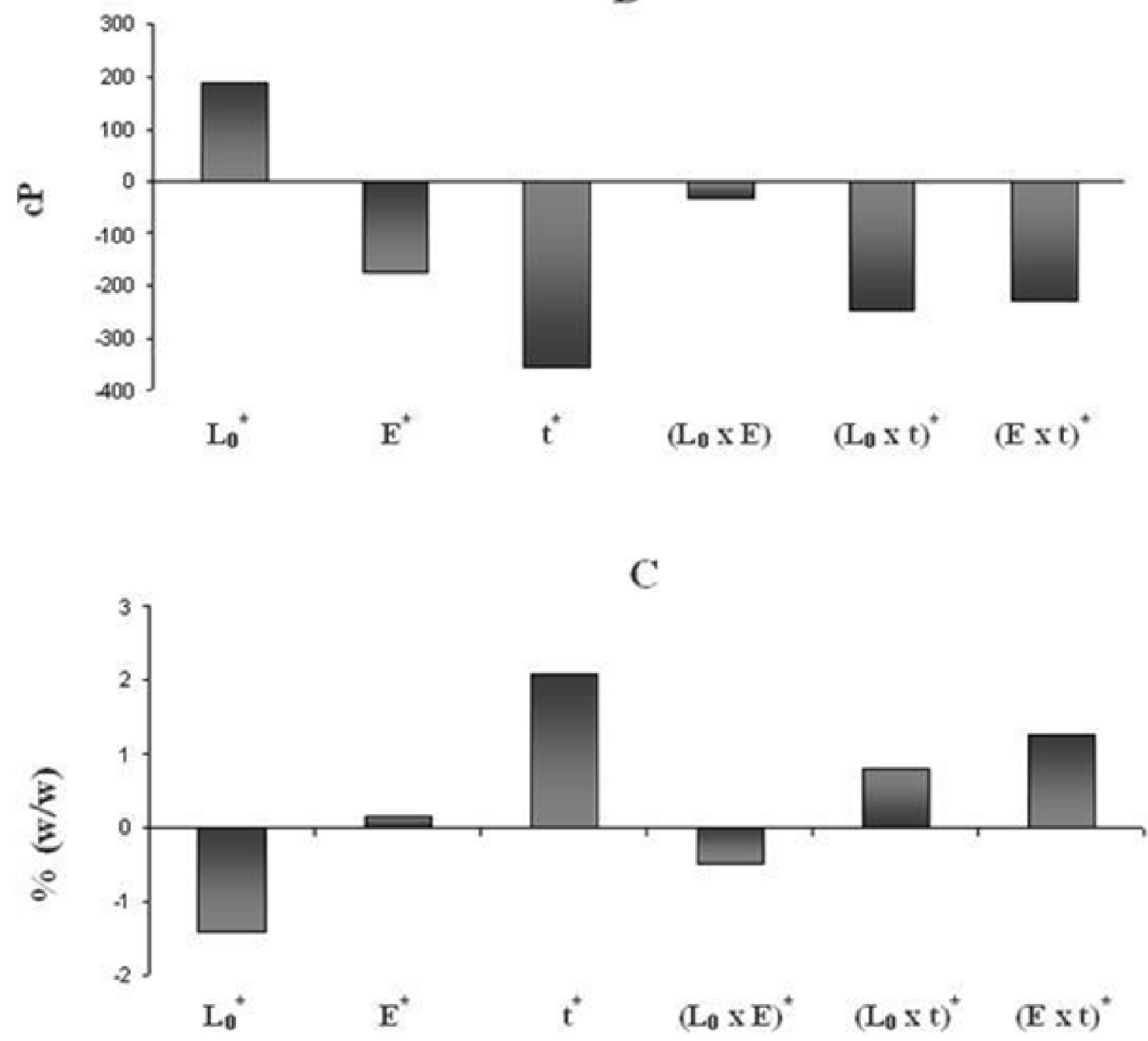

Figure 2 - Main effects and the effects of interaction $\left({ }^{*} p \leq 0.05\right)$ on processing time (A), viscosity (B) and syneresis (C). 
The increase from 59 to $91 \mathrm{~g} \mathrm{~L}^{-1}$ in the initial lactose concentration was significant for all the responses, increasing processing time and viscosity by an average of $0.12 \mathrm{~h}$ and $190 \mathrm{cP}$, respectively, and reducing syneresis by $1.41 \% \mathrm{w} / \mathrm{w}$.

Syneresis is a common defect in fermented dairy product processing and it has to do with the appearance of liquid on the milk gel surfaces and gel shrinkage, with consequent milk whey loss (GAUCHE et al., 2009). Therefore, the addition of whey improved the physical properties of the yogurt, resulting in higher viscosity and lower syneresis levels. This fact can be associated with the presence of whey proteins in increasing concentrations, favoring protein interactions and proteinprotein bonds that influence the elastic character of the gel, making the yogurt less susceptible to rupture (DAMIN et al., 2009). Moreover, the increase in the total solid content of the substrate increases the viscosity and stability of yogurt gel (GAUCHE, 2009). Concerning processing time, similar behavior was observed for milk supplemented with increasing concentrations of concentrated whey powder and skimmed milk powder in the manufacture of yogurt (DAMIN, 2009).

The reduction in viscosity $(175 \mathrm{cP})$ and the increase in syneresis $(0.16 \% \mathrm{w} / \mathrm{w})$ that were observed with the increase in $\beta$-galactosidase concentration from 0.5 to $1.0 \mathrm{~g}$ $\mathrm{L}^{-1}$ may be associated with the reduction in the formation of exopolysaccharides (EPS) by lactic acid bacteria. According to Canilha et al. (2006), glycosyl hydrolases are responsible for the degradation of EPS in long fermentation and the income in the production of these polysaccharides depends on the optimal $\mathrm{pH}$ for action of lactic acid bacteria and endogenous enzymes. As the exogenous enzyme used is a typical glycosyl hydrolase, which acts in different $\mathrm{pH}$ ranges during fermentation, it is assumed that further addition of enzyme may reduce the amount of EPS formed, with a consequent negative impact on viscosity and separation phases. Moreover, processing time increased by $0.11 \mathrm{~h}$.

The increase in the time of addition of the enzyme from the beginning of the fermentation process $(0 \mathrm{~h})$ to $1 \mathrm{~h}$ after the addition of lactic culture showed an increase in processing time of $0.29 \mathrm{~h}$, a significant increase of $2.09 \%$ $\mathrm{w} / \mathrm{w}$ in syneresis and a significant decrease of $353 \mathrm{cP}$ in viscosity. The negative impact on these physical quality properties can be related to the lower denaturation of the enzymes as a result of less contact time, leading to a more pronounced effect, for example, on the hydrolisis of EPS during gel formation. It is important to note that this variable had the greatest effects on processing time, viscosity and syneresis.
The interactions between the initial lactose concentration and enzyme concentration were significant only for the syneresis. The combination of increasing lactose concentration and increasing enzyme concentration with the increase in the time of addition of the enzyme (Lo x t and E x t, respectively) had a significant effect on both viscosity and syneresis.

\section{Conditions for the production of a yogurt with low lactose content in a single-stage process}

Based on the results presented here and considering that the main goal of this work is the production of a yogurt with low lactose content without any alteration to the physical quality properties (viscosity, and syneresis) in comparison to the control fermentations (with no added enzymes), it is clear that Run 2 and Run 4 (Table 2) used process conditions that resulted in a product with viscosity (2343 and $2193 \mathrm{cP}$, respectively) in the same range observed in the control fermentations.

Corroborating these results, when analyzing the effects it was observed that for greater viscosity associated with a lower level of syneresis, the best process conditions are found in Run 2 and Run 4 (Table 2), owing to the significant interactions between the parameters observed previously.

Therefore, although the highest conversion of lactose was achieved in Run 3 (Table 2), this product had less viscosity $(1962 \mathrm{cP})$ than the conventional process $(2013 \mathrm{cP})$. However, by using an initial lactose concentration of $91 \mathrm{~g} \mathrm{~L}^{-1}$, enzyme concentration of $0.5 \mathrm{~g} \mathrm{~L}^{-1}$ and the addition of enzyme at the beginning of fermentation together with the lactic culture (Run 2), a lactose conversion of $97.9 \%$ was obtained, with a process time of $3.68 \mathrm{~h}$, viscosity of $2343 \mathrm{cP}$ and syneresis of $74.79 \% \mathrm{w} / \mathrm{w}$, corresponding to a reduction of only $1.8 \%$ in lactose conversion and practically the same processing time in relation to Run 3 . Under the same conditions of lactose concentration and the time of addition of the enzyme with an enzyme concentration of $1.0 \mathrm{~g} \mathrm{~L}^{-1}$ (Run 4), a lactose conversion of $99.2 \%$ was achieved with a process time of $3.85 \mathrm{~h}$, viscosity of $2193 \mathrm{cP}$ and syneresis at $73.94 \% \mathrm{w} / \mathrm{w}$, with a reduction of only $0.5 \%$ of lactose conversion in relation to Run 3.

Since, from an economic viewpoint, it is more interesting to have less enzyme concentration and a shorter processing time, the process conditions of Run 2 were considered the most satisfactory, taking into account that the lactose conversion obtained was far higher than any mentioned in the literature (TOBA; ARIHARA; ADACHI, 1986; LONGO; WASZSCZYNSKVJ, 2006; RODRIGUEZ; 
CRAVERO; ALONSO, 2008), with a residual lactose concentration of only $1.9 \mathrm{~g} \mathrm{~L}^{-1}$. This is far lower, for instance, than the findings of Rodriguez, Cravero and Alonso (2008), approximately $7.7 \mathrm{~g} \mathrm{~L}^{-1}$ for goat milk yogurt. It is also important to emphasize that it was possible to maintain the physical and chemical characteristics of viscosity and syneresis associated with significant gains in productivity through a reduced processing time of approximately $19 \%$, compared to the process without enzyme addition. This fact is highly relevant, considering that Longo and Waszczynskyj (2006) found an increase of approximately $15 \%$ in fermentation time, comparing substrates with identical compositions, one with reduced lactose in a previous enzymatic stage and another without previous lactose reduction. This result indicates that lactose conversion prior to fermentation contribute to the increase in the time of the fermentation process, being another important restriction of the process in multiple stages. In the present study, with a single-stage process, there was a reduction in process time in relation to fermentation without enzyme.

\section{CONCLUSION}

The selected processing conditions (initial lactose concentration of $91 \mathrm{~g} \mathrm{~L}^{-1}$, enzyme concentration of $0.5 \mathrm{~g} \mathrm{~L}^{-1}$ and the enzyme addition at the beginning of fermentation) resulted in a product with similar viscosity $(2343 \mathrm{cP})$ and syneresis $(74.79 \% \mathrm{w} / \mathrm{w})$ when compared with the same substrate without enzyme addition (2451 cP and $76.30 \% \mathrm{w} / \mathrm{w}$, respectively) and high lactose conversion (97.9\%). Furthermore, processing time was reduced by approximately $19 \%$ (from 4.55 to $3.68 \mathrm{~h}$ ).

\section{ACKNOWLEDGEMENTS}

The authors would like to thank BR Foods, Chr Hansen and Prozyn for the material support and CNPq and FAPERGS for their financial support.

\section{REFERENCES}

AMATAYAKUL, T.; SHERKAT, F.; SHAH, N.P. Syneresis in set yogurt as affected by EPS starter cultures and levels of solid. International Journal of Dairy Technology, Oxford, v.59, n.3, p.216-221, 2006.

CANILHA, L. et al. Aditivos alimentares produzidos por via fermentativa parte 3: polissacarídeos e enzimas. Revista Analytica, São Paulo, v.20, p.32$41,2006$.
DAMIN, M.R. et al. Effects of milk supplementation with skim milk powder, whey protein concentrate and sodium caseinate on acidification kinetics, rheological properties and structure of nonfat stirred yogurt. LWT - Food Science and Technology, Zurich, v.42, p.17441750, 2009.

EUROPEAN FOOD SAFETYAUTHORITY-EFSA. Scientific opinion on lactose thresholds in lactose intolerance and galactosaemia. EFSA Journal, Parma, v.8, n.9, p.1-29, 2010. Available in: < http:// www.efsa.europa.eu/de/scdocs/doc/1777.pdf >. Access in: jun. 26, 2012.

FANARO, S. et al. Galacto-oligosaccharides are bifidogenic and safe at weaning: a double-blind randomized multicenter study. Journal of Pediatric Gastroenterology \& Nutrition, Jerusalem, v.48, n.1, p.8288, 2009.

GAUCHE, C. et al., Physical properties of yogurt manufactured with milk whey and transglutaminase. LWT - Food Science and Technology, Zurich, v.42, n.1, p.239-243, 2009.

GROSOVÁ,Z:; ROSENBERG, M.; REBROS, M. Perspectives and applications of immobilised $\beta$ galactosidase in food industry - a review. Czech Journal of Food Science, Praha, v.26, n.1, p.1-14, 2008.

JURADO, E. et al. Kinetic model for lactose hydrolysis in a recirculation hollow-fiber bioreactor. Chemical Engineering Science, St. Lucia, v.59, n.2, p.397-405, 2004.

LAMOUREUX, L.; ROY, D.; GAUTHIER, S.F. Production of oligosaccharides in yogurt containing bifidobacteria and yogurt cultures. Journal of Dairy Science, Champaign, v.85, n.5, p.1058-1069, 2002.

LONGO, G.; WASZCZYNSKYJ, N. Porcentagem de redução no teor de lactose na produção convencional de iogurte natural. Revista do Instituto de Laticínios Cândido Tostes, Juiz de Fora, v.61, n.351, p.371-373, 2006.

MARAFON, A.P. et al. Optimization of the rheological properties of probiotic yogurts supplemented with milk proteins. LWT - Food Science and Technology, Zurich, v.44,p.511-519, 2011. 
MARTINS, A.R. et al. Lactose conversion and the synthesis of galactooligosaccharides in a simultaneous lagged bioprocess using $\beta$-galactosidase and probiotic microorganisms. Brazilian Journal of Food Technology, Campinas, v.14,n.2, p.130-136, 2011.

RODRIGUEZ, V.A.; CRAVERO, B.F.; ALONSO, A.

Proceso de elaboración de yogur deslactosado de leche de cabra. Ciência e Tecnologia de Alimentos, Campinas, v.28, suppl., p.109-115, 2008.

SCHAAFSMA, G. Lactose and lactose derivatives as bioactive ingredients in human nutrition.
International Dairy Journal, Edmonton, v.18, n.5, p.458-465, 2008.

SWALLOW, D. M. Genetics of lactase persitence and lactose intolerance. Annual Review of Genetics, Palo Alto, v.37, p.197-219, 2003.

TOBA, T.; ARIHARA, K.; ADACHI, S. Quantitative changes in oligosaccharides during fermentation and storage of yogurt inoculated simultaneously with starter culture and $\beta$-galactosidase preparation. Journal of Dairy Science, Champaign, v.69, n.5, p.1241$1245,1986$. 